\title{
PENGGUNAAN BUKTI ELEKTRONIK DALAM PERADILAN PIDANA
}

\author{
Made Sugi Hartono \\ Ni Putu Rai Yuliartini \\ Prodi Ilmu Hukum, Jurusan Hukum dan Kewarganegaraan \\ Fakultas Hukum Dan Ilmu Sosial, Universitas Pendidikan Ganesha \\ Email: sugi.hartono@undiksha.ac.iddan raiyuliartini@undiksha.ac.id
}

\begin{abstract}
Abstrak
Dua hal yang menjadi sasaran dalam kajian ini yaitu: pertama, analisis proses penggunaan informasi/dokumen elektronik sebagai alat bukti dalam peradilan pidana dan, kedua untuk mengkonstruksi parameter dalam penentuan informasi/dokumen elektronik sebagai alat bukti dalam peradilan pidana. Dalam upaya mencapai sasaran tersebut, ditetapkan metode yuridis normatifempiris dengan pendekatan kasus, konseptual dan perundang-undangan. Kajian ini menggunakan data primer sebagai pokoknya yang dikumpulkan dengan teknik wawancara dan data sekunder yang terdiri dari bahan hukum primer, sekunder dan tersier sebagai tambahan yang dikumpulkan dengan teknik studi dokumen. Kumpulan data selanjutnya diolah dengan cara diseleksi, diklasifikasi dan disistematisasi yang kemudian dianalisis secara kualitatif melalui penyajian deskriptif-preskriptif. Proses tersebut dilaksanakan secara menyeluruh dengan mengkontekskan secara logis berdasarkan relevansinya dengan topik penelitian yang diangkat. Diujung penelitian ini diperoleh hasil dan kesimpulan bahwa prinsipnya hakim menentukan informasi/dokumen elektronik sebagai alat bukti dalam peradilan pidana melalui tiga langkah. Pertama, memastikan legalitas perolehan informasi/dokumen elektronik. Kedua, mengecek dokumen pendukung yang berupa hasil uji digital forensik. Ketiga, memberikan kesempatan bagi pihak lawan melakukan penyangkalan yang tentu dibarengi pembuktian akan dalilnya. Sementara, parameter yang digunakan hakim sampai pada informasi/dokumen elektronik dipertimbangkan dalam putusannya adalah dapat diakses; ditampilkan; dijamin keutuhannya; dan dipertanggungjawabkan.
\end{abstract}

Kata kunci: bukti elektronik, pembuktian, peradilan pidana.

\begin{abstract}
Two things are targeted in this study, namely: first, an analysis of the process of using electronic information/documents as evidence in criminal justice and, second, to construct parameters in determining electronic information/documents as evidence in criminal justice. In an effort to achieve these targets, normative-empirical juridical methods are used with case, conceptual and statute approaches. This study uses primary data as the basis collected by interview techniques and secondary data consisting of primary, secondary and tertiary legal materials in addition to those collected with document study techniques. The collection of data is then processed by selecting, classifying and systematizing which are then analyzed qualitatively through
\end{abstract}


descriptive-prescriptive presentation. The process is carried out thoroughly by logically contextualization based on its relevance to the research topics discussed. At the end of this study the results and conclusions were obtained that in principle the judge determined the information/electronic documents as evidence in criminal justice through three steps. First, ensuring the legality of obtaining information/electronic documents. Second, check supporting documents in the form of digital forensic test results. Third, it provides an opportunity for the opposing party to make a denial which is accompanied by proof of its argument. Meanwhile, the parameters used by the judge to the information/electronic documents considered in the decision are accessible; displayed; its integrity is guaranteed and accounted for.

Keywords: electronic evidence, proof, criminal justice. 


\section{Pendahuluan}

Mengawali tulisan ini, peneliti ingin mengutip suatu postulat dalam hukum pidana yang menyatakan"In criminalibus probantiones bedent esse luce clariores". Adegium ini mengandung arti bahwa dalam perkara pidana bukti itu harus lebih terang dari cahaya.Ungkapan ini menunjukkan betapa krusialnya suatu pembuktian dalam peradilan pidana sehingga dituntut untuk dilaksanakan secara terang benderang. Dalam suatu upaya menciptakan masyarakat madani, tuntutan akan suatu praktik peradilan pidana yang bermartabat dan beradab merupakan suatu keniscayaan. Hal demikian dilaksanakan dengan suatu due process of law termasuk dalam proses pembuktiannya. Bagaimanapun juga pengenaan pidana merupakan persoalan hak asasi manusia yang paling fundamental yaitu hak hidup dan kemerdekaan seseorang sehingga dilaksanakan secara terukur semaksimal mungkin merepresentasikan kebenaran absolut.

Realitas di abad 21 bahwa teknologi berkembang sedemikian pesat. Perkembangan teknologi tersebut membawa serta implikasi terhadap semua bidang kehidupan masyarakat baik itu sosial, budaya, pendidikan ekonomi, termasuk pula di bidang hukum. Dalam bidang hukum pidana misalnya, implikasi teknologi terlihat sangat nyata terutama dalam proses peradilan khususnya dalam hal pembuktian. Pasal 184 UndangUndang Nomor 8 Tahun 1981 Tentang Hukum Acara Pidana yang selanjutnya disebut dengan KUHAP mengatur bahwa alat bukti yang sah terdiri dari:
a. Keterangan saksi;
b. Keterangan ahli;
c. Surat;
d. Petunjuk;
e. Keterangan terdakwa.

Limitasi alat bukti sebagaimana yang diatur dalam KUHAP tersebut dalam perkembangannya tidak cukup mampu mengakomodir realitas yang ada di masyarakat dewasa ini. Pengungkapan kebenaran materiil terhadap tindak pidana yang terjadi tidak mempunyai nilai maksimal jika hanya berpaku pada kelima jenis alat bukti tersebut. Terdapat instrumen baru berbasis teknologi yang lebih merefleksikan kebenaran senyatanya. Seperti misalnya pada beberapa kasus, tindak pidana justru terungkap dengan adanya rekaman closed circuit television/CCTV(Saudale, 2017), atau misalnya percakapan elektronik (chat) melalui media sosial (Saputra, 2015). Model instrumen seperti ini yang tidak tercakup dalam alat bukti sebagaimana yang diatur dalam Pasal 184 KUHAP.

Kondisi dimana suatu aturan hukum tidak mampu lagi mengatur suatu peristiwa tertentu akibat adanya perkembangan masyarakat dikatakan dalam Bahasa Belandadengan istilah "De wet hinkt achter de feiten aan" yaitu suatu keadaan dimana hukum dirumuskan dalam kata-kata selalu tertinggal terhadap perubahan yang terjadi pada masyarakat yang seharusnya dikontrol atau dikendalikan olehnya. Keadaan 
inilah yang selanjutnya dipertegas oleh Satjipto Rahardjo dengan menyatakan "tidak ada undangundang yang abadi, oleh karena undang-undang itu perumusan yang pasti, sementara ia harus berhadapan dengan kehidupan yang harus berubah" (Suhardin, 2009:342).

Ketertinggalan hukum menjadi dasar bagi pemerintah untuk membentuk suatu aturan yang mampu menjadi payung terhadap perkembangan teknologi beserta eksesnya di masyarakat. Instrumen hukum yang dimaksud adalah Undang-Undang No. 11 Tahun 2008 jo Undang-Undang No. 19 Tahun 2016 Tentang Informasi Dan Transaksi Elektronik yang selanjutnya disebut dengan UU ITE. Setidaknya terdapat dua poin dalam bagian konsideran yang menjadikan alasan tersebut sebagai dasar dibentuknyaUU ITE.Pertama huruf c yang pada intinya menyatakan bahwa dengan pesatnya perkembangan dan kemajuan teknologi informasi mengakibatkan perubahan kehidupan masyarakat yang secara langsung mempengaruhi bentuk-bentuk perbuatan hukum baru. Kedua, huruf $f$ yang menyatakan bahwa dibutuhkan upaya pemerintah untuk mendukung pengembangan teknologi informasi melalui instruktur hukum dan pengaturannya sehingga pemanfaatan teknologi informasi dilakukan secara aman untuk mencegah penyalahgunaannya dengan memperhatikan nilai-nilai agama dan sosial budaya masyarakat Indonesia.
Bertalian dengan alat bukti, pada Pasal 5 UU ITE diatur sebagai berikut: (1) Informasi elektronik dan/atau dokumen elektronik dan/atau hasil cetaknya merupakan alat bukti hukum yang sah; (2) Informasi elektronik dan/atau dokumen elektronik dan/atau hasil cetaknya merupakan perluasan dari alat bukti yang sah sesuai dengan hukum acara yang berlaku di Indonesia; (3) Informasi elektronik dan/atau dokumen elektronik dinyatakan sah apabila menggunakan sistem elektronik sesuai dengan ketentuan. Sementara itu, apabila kita melihat ketentuan Pasal 1 UU ITE angka 1 menyatakan bahwa informasi elektronik adalah satu atau sekumpulan data elektronik, termasuk tetapi tidak terbatas pada tulisan, suara, gambar, peta, rancangan, foto, electronic data interchange (EDI), surat elektronik (electronic mail), telegram, teleks, telecopy, atau sejenisnya, huruf, tanda, angka, Kode Akses, simbol atau perforasi yang telah diolah, yang memiliki arti atau dapat dipahami oleh orang yang mampu memahaminya. Selanjutnya pada angka 4 menyatakan bahwa dokumen elektronik adalah setiap informasi elektronik dibuat, diteruskan, dikirimkan, diterima atau disimpan dalam bentuk analog, digital, elektromagnetik, optikal atau sejenisnya, yang dapat dilihat ditampilkan dan/atau didengar, melalui komputer atau sistem elektronik, termasuk tetapi tidak terbatas pada tulisan, suara, gambar, peta, rancangan, foto atau sejenisnya, huruf, tanda, angka, kode akses, simbol atau perforasi 
yang memiliki makna atau arti atau dapat dipahami oleh orang yang mampu memahaminya.

Ketentuan sebagaimana yang diatur dalam Pasal 1 angka 1 dan 4 serta Pasal 5 ayat (1) dan (2) UU ITE merupakan ketentuan yang luas sifatnya sehingga berpotensi multi tafsir. Hal demikian bertentangan dengan asas legalitas sebagai salah satu asas fundamental dalam hukum pidana yang mempunyai salah satu makna bahwa peraturan hukum pidana bersifat lex certa (peraturan sifatnya jelas tidak boleh multi tafsir). Oleh karenanya dibutuhkan suatu pembatasan yang mampu memperjelas lingkup ketentuan pasal tersebut baik secara yuridis dalam bentuk peraturan ataupun secara sosiologis yaitu penerapannya pada proses peradilan pidana.

Batasan yang begitu luas mengenai bukti elektronik bersifat problematis pada tataran aplikasi penanganan suatu perkara pidana. Terutama bagi seorang hakim dengan tugas mengadili yang mendasarkan putusannya pada ketersediaan alat bukti melalui proses pembuktian. Momentum krusial bagi hakim dalam hal ini yaitu ketika menentukan apakah suatu alat bukti elektronik dapat digunakan sebagai alat bukti ataukah tidak. Hakim hendaknya mempunyai pedoman dan prosedur dalam menentukan kualifikasi bukti elektronik sebagai alat bukti.Begitu pula parameter yang digunakan sebagai ukuran dalam menyeleksi kualifikasi bukti elektronik tertentu sehingga dapat digunakan sebagai alat bukti yang sah dalam peradilan pidana.
Menyikapi hal tersebut di atas, maka dibutuhkan suatu kajian dalam bentuk legal research yang muaranya mampu mendeskripsikan proses penentuan bukti elektronik sebagai alat bukti dalam peradilan pidana serta menemukan parameter yang digunakan sebagai mekanisme seleksi untuk memenuhi kualifikasi alat bukti pada peradilan pidana. Kajian ini urgent sifatnya setidaknya untuk beberapa hal.Pertama, memperjelas batasan mengenai bukti elektronik sebagaimana yang disebutkan dalam Pasal 5 ayat (1) dan (2) UU ITE. Hal demikian penting sebagai tuntutan pemenuhan asas legalitas yang pada gilirannya berimplikasi pada praktik peradilan sebagai jaminan atas kepastian hukum sebagaimana cita hukum yang disampaikan oleh Gustav Radbruch dalam Radbruch Formula. Kedua, Menciptakan standar pedoman bagi aparat penegak hukum baik kepolisian sebagai penyidik, kejaksaan sebagai penuntut umum, advokat sebagai penasihat hukum, dan hakim sendiri sebagai pengadil. Pedoman dibutuhkan agar tercipta kesamaan interpretasi sehingga terjadi keterpaduan diantara subsistem dalam sistem peradilan pidana. Ketiga, menciptakan keteraturan dalam pelaksanaan pembuktian perkara pidana khususnya menyangkut penggunaan alat bukti elektronik. Pemahaman dan interpretasi yang seragam di kalangan aparat penegak hukum mampu meminimalisir kemungkinan adanya perdebatan sehingga proses dapat berjalan dengan baik. Berdasarkan ketiga argumentasi tersebut maka kajian 
ini mempunyai urgensi dan relevansi terkait dengan problematika hukum yang nyata di dunia praktis.

\section{Rumusan Masalah}

Berdasarkan uraian sebelumnya, dapat dirumuskan dua masalah substansial sebagai berikut:

1. Bagaimanakah hakim menentukan suatu informasi/dokumen elektronik yang dapat digunakan sebagai alat bukti dalam peradilan pidana?

2. Apakah parameter suatu informasi/dokumen elektronik agar dapat digunakan sebagai alat bukti dalam peradilan pidana? 
Pembahasan

\section{Peradilan Pidana Sebagai Upaya Penggalian Kebenaran Materiil}

Mengawali uraian tentang peradilan pidana sebagai upaya penggalian kebenaran materiil, terlebih dahulu akan dijelaskan mengenai definisi peradilan pidana itu sendiri. Peradilan sendiri dipahami sebagai suatu proses yang dilakukan oleh pihak-pihak yang berwenang dengan tujuan menegakkankeadilan sehingga tercipta ketertiban dan ketenteraman dalam masyarakat (Bahri, 1996: 240). Dalam konteks Indonesia peradilan didasarkan pada Pancasila sebagai rechtsidee bangsa dan UUD 1945 sebagai statgrundgesetz dalam teori Hans Nawiasky. Sementara itu pidana dipahami sebagai penderitaan yang secara sengaja ditimpakan terhadap seseorang yang telah melakukan perbuatanyang memenuhi syaratsyarat tertentu (Siswanto, 2007: 7). Dengan demikian dapat dipahami bahwa peradilan pidana merupakan suatu proses dalam rangka menegakkan keadilan pada perkara pidana sehingga tercipta ketertiban dan ketenteraman di masyarkat.

Peradilan pidana dilaksanakan berdasarkan hukum acara pidana melalui terbagi ke dalam beberapa tahapan.Masing-masing tahapan yang melibatkan institusi tertentu. Mengikuti pemikiran Sudikno Mertokusumo peradilan pidana terdiri tiga tahap yaitu: tahap pendahuluan atau permulaan, tahap penentuan dan terakhir tahap pelaksanaan (Mertokusumo, 1996: 74). Tahap pendahuluan yaitu penyelidikan dan penyidikan yang dilaksanakan oleh kepolisian sebagaimana diatur di dalam Pasal 1 angka 1, 2, 4 dan 5 KUHAP, tahap penuntutan yang dilaksanakan oleh kejaksaan sebagaimana yang diatur dalam Pasal 1 angka 6 dan 7 KUHAP.Tahap penentuan terdiri dari pemeriksaan di sidang pengadilan, pembuktian dan putusan hakim.Sementara, tahap pelaksanaan atau eksekusi terdiri dari pelaksanaan putusan oleh jaksa serta pengawasan dan pengamatan pelaksanaan putusan hakim.

Peradilan pidana pada prinsipnya sarat akan nilai-nilai kemanusiaan. Jika dikaitkan dengan jenis sanksi pidana sebagaimana yang diatur di dalam Pasal 10 KUHP yaitu pidana mati, penjara, kurungan, denda dan tutupan, maka pengenaan sanksi pidana kepada seseorang merupakan bentuk perampasan hak asasi manusia yang sifatnya fundamental. Berangkat dari hal demikian maka peradilan pidana dilaksanakan dengan jalan mencari materiele waarheid atau yaitu kebenaran yang sesungguhnya terjadi atau kebenaran riil.Pandangan demikian dikemukakan oleh L.J. van Apeldoorn yang menyatakan bahwa berbeda dengan hakim pada peradilan perdata yang menggali kebenaran formil maka hakim pada perkara pidana harus menggali kebenaran materiil (Apeldoorn, 1978: 263).

Upaya penggalian materiele waarheid dalam peradilan pidana dilaksanakan dalam proses pembuktian. Berkaitan dengan pembuktian dikenal suatu asas yang menyatakan actori incumbit probatia yaitu dalam hal salah satu pihak mengemukakan atau membantah 
suatu peristiwa maka yang bersangkutan harus membuktikannya. Merujuk pada asas tersebut maka beban pembuktian atau bewijslast dalam perkara pidana secara umum ada pada jaksa sebagai penuntut umum.Konsep tersebut dipertegas sebagaimana yang tersirat dalam ketentuan Pasal 66 KUHAP yang mengatur bahwa tersangka atau terdakwa tidak dibebani kewajiban pembuktian.Ketentuan ini berdasarkan interpretasi a contrario dipahami bahwa yang mempunyai kewajiban membuktikan adalah jaksa selaku penuntut umum.

Berdasarkan uraian tersebut sebelumnya dapat dipahami bahwa peradilan pidana merupakan upaya untuk menggali kebenaran materiil sebab dalam pidana sendiri inheren pelanggaran hak asasi manusia sehingga prosesnya dilaksanakan secara terukur.

\section{Pembuktian Dalam Peradilan Pidana}

Pembuktian pada perkara pidana pada prinsipnya merupakan suatu proses untuk menemukan dan menyatakan tentang kebenaran materiil mengenai tindak pidana dan kesalahan yang dilakukan oleh seseorang sehingga terhadap orang tersebut dapat dikenakan pidana. Proses pembuktian diatur dalam hukum acara sehingga pelaksanaanya mempunyai batasan yaitu terkait dengan alat bukti yang dapat digunakan termasuk pula penilaian terhadap alat bukti tersebut. Baik penuntut umum ataupun terdakwa melaui penasihat hukumnya tidak secara bebas dapat mengajukan alat bukti yang dianggapnya benar, sehingga dalam hal ini peran hakim menjadi sangat vital dalam menilai dan mempertimbangkan kekuatan pembuktian suatu alat bukti. Hakim hendaknya mendasarkan pada alat bukti yang secara limitatif disebutkan dalam undang-undang (Ipakit, 2015: 89).

$\mathrm{R}$ Supomo mengajukan dua gagasan mengenai arti penting pembuktian. Pertama, pembuktian penting sebagai upaya pembenaran hubungan hukum. Adanya pembuktian dalam memperkuat kesimpulan hakim berbasis pada syarat-syarat bukti yang sah. Olehnya ini disebut dengan pembuktian dalam arti luas. Kedua, pembuktian penting dalam hal apa yang dikemukakan oleh penggugat dibantah oleh tergugat. Hal-hal yang tidak dibantah tidak membutuhkan pembuktian. Ini selanjutnya disebut pembuktian dalam arti yang terbatas (Eddy O.S. Hiariej, 2012: 6). Mirip dengan pikiran R. Supomo, Sudikno Mertokusumo mengemukakan tentang apa yang disebut dengan arti pembuktian secara yuridis. Baginya pembuktian dapat dilihat dalam arti yuridis sebagai upaya memberikan dasar-dasar yang cukup kepada hakim pemeriksa perkara sehingga memberikan kepastian terhadap kebenaran suatu peristiwa yang didalilkan (Eddy O.S. Hiariej, 2012: 7).

Dengan substansi yang sama Eddy O.S. Hiariej merumuskan gagasan tentang arti pentingnya suatu pembuktian sebagai langkah mencari kebenaran atas suatu peristiwa. Sering kali digaungkan bahwa peradilan pidana adalah 
pencarian terhadap kebenaran materiil. Jikalau demikian, pembuktian merupakan konsekuensi logis sebab esesnsi dari pembuktian sendiri adalah mencari kebenaran terhadap peristiwa hukum. Maka tidak salah jika dalam persidangan perkara pidana momentum krusialnya ada pada titik pembuktian. Tidak hanya itu, masih menyangkut persidangan pidana, upaya pembuktian bahkan telah dilakukan pada tahap penyelidikan sebagai tahap penemuan peristiwa yang diduga sebagai tindak pidana guna dapat atau tidaknya dilakukan penyidikan. Oleh karenanya, hukum pembuktian dibutuhkan untuk mencari kebenaran atas suatu peristiwa hukum yaitu peristiwa yang mempunyai akibat hukum (Eddy O.S. Hiariej, 2012: 7).

Dalam proses pembuktian yang menjadi dasar acuan adalah dakwaan yang sebelumnya telah disusun oleh jaksa selaku penuntut umum. Dakwaan mengandung pasal-pasal yang dituduhkan kepada terdakwa. Sehingga untuk sampai pada kesimpulan bahwa terdakwa terbukti melakukan tindak pidana seperti yang dituduhkan maka unsur-unsur yang terkandung dalam pasal tersebut harus dibuktikan terlebih dahulu (Kalia, 2013:7). Mengenai alat bukti, hal ini merujuk pada ketentuan Pasal 184 KUHAP yang menyatakan bahwa alat bukti yang adalah keterangan saksi, keterangan ahli, surat, petunjuk dan keterangan terdakwa. Jenis alat bukti mengalami perkembangan dengan adanya UU ITE yang mana berdasarkan pada ketentuan Pasal 5 ayat (1) dan (2) bahwa informasi elektronik dan atau dokumen elektronik dan atau hasil cetaknya juga merupakan alat bukti yang sah sehingga dapat digunakan dalam peradilan pidana.

Penjatuhan putusan oleh hakim pada perkara pidana sangat ditentukan oleh proses pembuktian. Dalam hal hakim menilai bahwa perbuatan terdakwa terbukti secara sah dan meyakinkan pelaku kemungkinan besar dijatuhi pidana. Begitu pula sebaliknya apabila tidak terbukti secara sah dan meyakinkan maka terdakwa dibebaskan. Hakim dalam menjatuhkan putusan berupa pemidanaan didasarkan pada dua alat bukti beserta keyakinan yang ada padanya. Ketentuan ini diatur di dalam Pasal 183 KUHAP yang secara teoritik dipandang sebagai negatief wettelijke bewijs theorie atau teori pembuktian berdasar undangundang secara negatif (Yusuf, 2013:217).

\section{Prihal Bukti Elektronik}

$\begin{array}{ccr}\begin{array}{c}\text { Secara } \\ \text { dokumen }\end{array} & \begin{array}{l}\text { historis } \\ \text { elektronik }\end{array} & \text { eksistensi } \\ \text { dalam }\end{array}$
peradilan pertama kali memperoleh legitimasi yuridis melalui Surat Edaran Mahkamah Agung (SEMA) Nomor 14 Tahun 2010 Tentang Dokumen Elektronik yang merupakan kelengkapan Permohonan Kasasi dan Peninjauan Kembali. Tujuannya adalah untuk meningkatkan efisiensi dan efektivitas proses minutasi berkas perkara serta mendukung transparansi dan akuntanbilitas pelayanan publik oleh MA beserta peradilan yang ada di bawahnya. Menariknya SEMA ini tidak mengatur dokumen elektronik 
sebagai alat bukti akan tetapi bicara soal dokumen elektronik berupa putusan ataupun dakwaan dalam suatu compact disc, flashdisk, trnasfer melalui email sebagai kelengkapan suatu permohonan kasasi dan peninjauan kembali ( Riki Perdana Raya Waruwu, 2019).

Berdasarkan Pasal 5 ayat (1) UU ITE pada prinsipnya bukti elektronik dapat diklasifikasikan menjadi dua yaitu: informasi dan/atau dokumen elektronik dan hasil cetak dari informasi elektronik dan atau hasil cetak dari Dokumen Elektronik. Informasi dan/atau dokumen elektronik selanjutnya dikualifikasikan sebagai alat bukti elektronik atau digital evidence, sementara hasil cetak dari Informasi dan/atau dokumen elektronik selanjutnya dikualifikasikan sebagai alat bukti surat.

Alat bukti sebagaimana disebutkan dalam Pasal 5 ayat (1) selanjutnya disebut sebagai perluasan dari alat bukti hukum sebagaimana hukum acara yang berlaku di Indonesia. Adapun maksud perluasan di sini yaitu: Pertama, menambah alat bukti yang telah diatur dalam hukum acara pidana di Indonesia sehingga menambah jenis alat bukti seperti yang diatur di dalam KUHAP. Kedua, memperluas cakupan alat bukti yang telah diatur dalam hukum acara pidana di Indonesia. Hal ini berkaitan dengan hasil cetak dari Informasi dan/atau dokumen elektronik yang merupakan alat bukti surat sebagaimana diatur dalam KUHAP. Bertalian dengan perluasan alat bukti dalam hukum acara pidana di Indonesia sesungguhnya diatur tersebar di berbagai peraturan perundangundangan misalnya UndangUndang Dokumen Perusahaan, Undang-Undang Terorisme, Undang-Undang Pemerantasan Tindak Pidana Korupsi dan lain sebagainya.

Pandangan bertalian dengan alat bukti elektronik sebetulnya berhadapan pada dua sisi yang memandang sebagai perluasan alat bukti surat dan sebagai petunjuk. Arief Indra K.A. melihat alat bukti elektronik dapat dikualifikasikan ke dalam dua pilihan yaitu: sebagai alat bukti surat atau alat bukti petunjuk. Sepanjang dibuat dalam bentuk cetak maka alat bukti elektronik menjadi alat bukti surat; dan bila memiliki keterkaitan dengan alat bukti lain yang semua kekuatannya bebas maka dapat dikatakan sebagai alat bukti pentunjuk (Abi Ja'man Kurnia, 2019).

Muhammad Nuh Al-Azhar menyatakan hal yang sama bahwa dalam perakteknya terdapat dua pandangan dikalangan aparat penegak hukum baik jaksa maupun hakim mengenai keberadaan bukti elektronik. Satu pihak ada yang menganggap bahwa informasi dan/dan atau dokumen elektronik sebagai alat bukti ke enam. Sementara pihak lainnya memandang bukti elektronik sebagai perluasan alat bukti sebagaimana yang diatur di dalam Pasal 184 Ayat (1) KUHAP. Keabsahan bukti elektronik diterangkan oleh seorang ahli digital forensik dalam proses persidangan. Prinsip yang melekat dalam pembuktian yaitu every evidence can talk, dengan kata lain 
yang menjadikan bukti elektronik dapat berbicara adalah seorang ahli (Dimas Hutomo, 2019).

Kiranya kedua pandangan ini mempunyai sisi benar, kendatipun tidak sepenuhnya dapat diterima. Sebagai alat bukti surat misalnya, jika dilihat pengertiannya dalam Pasal 184 KUHAP dapat dipahami dalam sifatnya yang konvensional. Padahal, realitanya alat bukti dokumen elektronik tidak terbatas pada tulisan akan tetapi lebih luas menyangkut suara, gambar, peta, foto, huruf, tanda, angka dan lain sebagainya. Begitu pula pandangan yang melihat dokumen elektronik sebagai petunjuk, tidak sepenuhnya bisa dianut sebab petunjuk pada dasarnya tidak bisa berdiri sendiri atau eksistensinya membutuhkan alat bukti lain. Lain halnya dengan dokumen elektronik yang pada saat tertentu justru menjadi alat bukti utama Khususnya menyangkut cybercrime. Akhirnya bisa dipahami bahwa dokumen elektronik merupakan alat bukti yang berdiri sendiri tidak terikat pada konsep sebagai perluasan alat bukti surat ataupun petunjuk (Nur Laili Isma dan Arima Koyimatun, 2014: 112).

Dokumen elektronik yang dijadikan sebagai alat bukti mempunyai sifat mudah berubah, rusak, hancur, jika tidak ditangani dan diuji dengan benar. Ketidakcermatand alam melakukan pemeriksaan suatu dokumen elektronik maka akan membawa pada kesimpulan salah. Biasanya dokumen elektronik sering tersembunyi, dapat melewati perbatasan dengan mudah dancepat, kadang kala bersifat timesensitive. Oleh karenanya, dalam rangka menentukan orisinalitas dari suatu bukti elektronik dibutuhkan suatu proses forensik. Proses itu terdiri dari collecting (pengumpulan), examination (pengujian), analysis (analisa), dan reporting (pelaporan). Pengumpulan dilaksanakan dengan mencari dan mendokumentasikan bukti elektronik serta melakukan pencegahan terhadap simpanan informasi yang mudah hilang. Sementara pengujian dibutuhkan agar bukti elektronik dapat dilihat serta menentukan baik asal ataupun keasliannya. Analisa sendiri dilakukan oleh investigator dan dalam beberap organisasi baik pengujian dan analisis dapat dilakukan oleh orang yang sama. Terakhir, pelaporan dilaksanakan dengan menuliskan proses pengujian dan catatan-catatan pada proses ini penting disimpan untuk pemberian keterangan dalam suatu kesaksian (Achmad Benny Mutiara, 2007: 79)

\section{Proses Hakim Menentukan Bukti Elektronik Yang Dapat Digunakan Sebagai Alat Bukti Dalam Peradilan Pidana}

Dalam rangka menghindari bias interpretasi terlebih dahulu peneliti menguraikan konteks pembuktian dalam suatu peradilan pidana. Bagaimanapun topik yang dibahas pada sub bab ini merupakan bagian dari lingkup pembuktian dalam peradilan pidana. Prinsipnya pembuktian dapat dikatakan sebagai substansi dari peradilan itu sendiri. Mengapa demikian, sebab kesalahan dari terdakwa akan diuji dalam proses pembuktian. Merujuk pada Pasal 197 KUHAP khususnya 
ayat (1) angka d. menyatakan bahwa surat putusan pemidanaan memuat salah satunya yaitu pertimbangan yang disusun secara ringkas mengenai fakta dan keadaan beserta alat-pembuktian yang diperoleh dari pemeriksaan di sidang yang menjadi dasar penentuan kesalahan terdakwa. Secara eksplisit ketentuan ini mengandung makna bahwa dalam penjatuhan pidana atau pemidanaan terhadap seseorang salah satunya didasarkan pada alat bukti yang terungkap dalam pembuktian pada proses sidang pengadilan.

Sidang pembuktian dalam peradilan pidana lazimnya dilakukan setelah adanya putusan sela (jika terdakwa mengajukan eksepsi/tangkisan).Dalam khasanah keilmuan hukum dikenal adanya adegium "actory in cumbit probation" yang artinya kurang lebih siapa yang mendalilkan suatu hak maka yang bersangkutanlah yang membuktikan. memang adegium ini lebih dikenal pada lapangan hukum perdata (ketentuan Pasal 163 HIR atau Pasal 283 R.Bg dan Pasal 1865 KUH Perdata) terkhusus bertalian dengan pihak-pihak yang mengklaim kepemilikan hak (Nugroho, 2015: 18). Kendati demikian adegium ini juga relevan dalam wilayah hukum pidana. KUHAP dalam Pasal 14 angka g mengatur tentang kewanangan penuntut umum yaitu melakukan penuntutan. Dalam kaitan dengan penuntutan inilah penuntut umum mempunyai kewajiban untuk membuktikan. Dengan demikian tegas bahwa beban atau kewajiban pembuktian pada perkara pidana secara umum merupakan tanggungjawab dari penuntut umum (Dahlan, 2015: 73).

Berbeda dengan penuntut umum, hakim mempunyai kewenangan untuk mengadili. Menurut ketentuan Pasal 1 angka 9 bahwa yang dimaksud dengan mengadili adalah serangkaian tindakan hakim untuk menerima, memeriksa dan memutus perkara pidana berdasarkan asas, bebas, jujur dan tidak memihak di sidang pengadilan. Konteks pembuktian adalah kewenangan hakim dalam hal memeriksa perkara. Artinya, hakim dengan kewenangannya memeriksa alat bukti yang diajukan baik oleh penuntut umum ataupun oleh penasihat hukum. Berdasarkan alat bukti inilah kemudian pada bagian akhir hakim akan menjatuhkan putusan diperkuat dengan keyakinan yang timbul karenanya.

Hakim bertugas memeriksa alat bukti dan barang bukti yang diajukan oleh penuntut umum dalam proses pembuktian. Alat bukti dan barang bukti tersebut tentunya merupakan yang relevan dan sah menurut ketentuan peraturan perundang undangan serta memenuhi syarat formil maupun materil. Dengan demikian, langkah pertama yang dilakukan hakim dalam menentukan suatu alat bukti yang dapat digunakan dalam peradilan pidana adalah menentukan relevansi dan keabsahannya. Bertalian dengan alat bukti khususnya informasi dan/atau dokumen elektronik secara tegas diatur dalam Pasal 5 UU ITE yang menyatakan bahwa informasi elektronik dan/atau 
dokumen elektronik dan/atau hasil cetaknya merupakan alat bukti hukum yang sah. Sementara yang dapat dijadikan barang bukti sehingga dapat disita menurut Pasal 39 ayat (1) KUHAP yaitu berupa:

a benda atau tagihan yang seluruh atau sebagian diduga diperoleh dari tindak pidana atau sebagai hasil dari tindak pidana;

b benda yang telah dipergunakan secara langsung untuk melakukan tindak pidana atau untuk mempersiapkannya;

c benda yang dipergunakan untuk menghalang-halangi penyidikan tindak pidana;

d benda yang khusus dibuat atau diperuntukkan melakukan tindak pidana;

e benda lain yang mempunyai hubungan langsung dengan tindak pidana yang dilakukan.

Sementara mengenai keabsahan barang bukti secara implisit diatur dalam Peraturan Kepala Kepolisian Negara Republik Indonesia No. 10 Tahun 2009 Pasal 2 ayat (1) yang menyebutkan bahwa peraturan ini bertujuan sebagai pedoman bagi petugas pelaksana penyidikan di lapangan dalam menangani tempat kejadian perkara dan barang bukti yang akan dimintakan pemeriksaan ke laboratorium forensik Polri. Sementara ayat (2)-nya menyatakan bahwa tujuan permintaan pemeriksaan ke Laboratoium Forensik Polri adalah untuk pembuktian secara ilmiah barang bukti. Ketentuan ini dapat dipahami bahwa keabsahan barang bukti dapat ditentukan melalui hasil pemeriksaan laboratorium forensik.
Mengenai siapa pihak yang dapat mengajukan pemeriksaan laboratorium forensik sebagaimana tersebut di atas ketentuannya dapat ditemukan pada Pasal 9 Peraturan Kepala Kepolisian Negara Republik Indonesia No. 10 Tahun 2009. Ayat (1)-nya menyebutkan bahwa pemeriksaan laboratoris kriminalistik barang bukti dapat dipenuhi berdasarkan permintaan tertulis dari: a. penyidik Polri; b. PPNS; c. Kejaksaan; d. Pengadilan; e. POM TNI; dan f. instansi lain sesuai dengan lingkup kewenangannya. Sementara pada ayat (2)-nya mengatur bahwa jenis barang bukti yang dapat dilakukan pemeriksaan oleh laboratorium forensik Polri meliputi: Pemeriksaan di bidang fisika forensik yang terdiri dari:

1. Deteksi kebohongan;

2. Analisa suara;

3. Perangkat elektronik, telekomunikasi, computer (bukti digital) dan penyebab proses elektrostatis;

4. Perlengkapan listrik, pemanfaatan energy listrik, dan pencurian listrik;

5. Pesawat pembangkit tenaga dan pesawat mekanis;

6. Peralatan produksi;

7. Konstruksi bangunan dan struktur bangunan;

8. Kebakaran/pembakaran;

9. Peralatan/bahan

redioaktif/nuklir;

10. Bekas jejak, bekas alat, rumah/anak kunci, dan pecahan kaca/keramik; dan

11. Kecelakaan kendaraan bermotor, kereta api, kendaraan air, dan pesawat udara. 
Terkait dengan bukti elektronik tentunya merujuk pada poin ketiga yaitu pemeriksaan laboratorium forensik terhadap Perangkat elektronik, telekomunikasi, computer (bukti digital) dan penyebab proses elektrostatis. Dengan demikian dapat dipahami bahwa langkah yang dilakukan oleh hakim dalam menentukan suatu bukti elektronik sebagai bukti dalam peradilan pidana yaitu dengan memeriksa kelengkapan pemeriksaan laboratorium forensik yang menyertai bukti elektronik tersebut.

Hal demikian juga ditegaskan melalui hasil wawancara peneliti dengan beberapa hakim yang bertugas di Pengadilan Negeri Kelas I BSingaraja atas nama I Nyoman Dipa Rudiana, S.E., S.H., M.H. dan I Gede Karang Anggayasa, S.H., M.H. Menurut yang bersangkutan hakim dalam menentukan suatu bukti elektronik yang dapat dijadikan bukti dalam peradilan pidana adalah dengan terlebih dahulu memeriksa kelengkapan hasil uji laboratorium forensik yang menyertainya. Bila hal tersebut tidak dilakukan maka tidak menutup kemungkinan bukti yang diajukan tidak dapat diterima.

Sebelumnya, dalam unjuk bukti elektronik yang dilakukan oleh penuntut umum, hakim mempunyai kesempatan untuk memeriksa sumber dan cara perolehannya. Tindakan ini penting dalam rangka menguji legalitas dari bukti yang diajukan. Tujuannya adalah jangan sampai bukti elektronik yang diajukan oleh penuntut umum diperoleh dari sumber dan dengan cara yang illegal. Bertalian dengan ini, menarik mencermati gagasan Eddy O.S. Hiariej tentang hal-hal fundamental dalam pembuktian. Sebagai esesnsi dalam peradilan pidana, menurutnya terdapat empat hal fundamental dalam pembuktian (Hiariej, 2012: 10-11). Pertama, bukti harus relevan dengan sengketa atau perkara yang sedang diperoses. Suatu bukti harus berkaitan dengan fakt-fakta yang menerangkan kebenaran suatu peristiwa. Kedua, suatu bukti haruslah dapat diterima admissible. Lazimnya, suatu bukti yang diterima otomatis relevan. Sebaliknya, belum tentu bukti yang relevan dapat diterima. Sangat mungkin terjadi bukti yang relevan akan tetapi tidak diterima seperti misalnya ketika bicara tentang apa yang disebut dengan testimoni de auditu atau hearsay yaitu mendengan kesaksian dari orang lain. Oleh karenanya, primafacie bukti yang diterima adalah bukti yang relevan. Ketiga, prinsip exclusionary rules atau diberbagai literatur dikenal dengan exclusionary discretion. Prinsip ini mempunyai kedalaman makna yang oleh Phyllis B. Gerstenfeld dikatakan bahwa bukti yang diperoleh secara melawan hukum tidak dapat diakui. Prinsip ini menjadi semacam aturan yang menentukan bahwa bukti yang diperoleh secara illegal tidak dapat diterima di pengadilan (Hiariej, 2012: 11). Dengan adanya prinsip exclusionary rules seorang terdakwa dapat mencegah penuntut umum mengajukan bukti dalam suatu persidangan sebagai bukti yang dapat diterima oleh karena diperoleh secara inkonstitusional. Dengan basis exclusionary rules, 
bukti probatif dapat ditolak yang konsekuensinya meniadakan tuntutan jaksa. Keempat, apa yang disebut dengan aksesibilitas hakim dalam mengevaluasi setiap bukti yang relevan dan dapat diterima. Prinsip ini bertalian erat dengan kekuatan pembuktian atau yang disebut dengan bewijskracht. Hakim mempunyai peran untuk menilai terhadap setiap bukti yang diajukan ke pengadilan, kesesuain antara bukti satu dengan lainnya yang selanjutnya menjadikan bukti-bukti tersebut sebagai dasar pertimbangan hakim dalam pengambilan putusan. (Hiariej, 2012: 12). Dengan demikian, dapat ditarik benang merah bahwa pemeriksaan mengenai asal muasal dan cara perolehan bukti elektronik yang dilakukan oleh hakim sejalan dengan prinsip exclusionary rules yang sifatnya fundamental.

Apa yang menjadi pandangan dari Hakim Dipa dan Karang, memperoleh legitimasi berdasarkan yurisprudensi pada Pengadilan Tinggi Bandung Nomor 178/Pid.Sus-ITE/2015/PT.BDG.

Adapun posisi kasusnya adalah sebagai beirkut:

Seorang istri yang bernama Wisni Yetty dilaporkan oleh suaminya yang bernama Heska Estika pada tanggal 6 Oktober 2013 atas dugaan melakukan tindakan asusila di jejaring sosial facebook dengan seorang pria bernamaNugraha Mursjid. Laporan tersebut ditindaklanjuti oleh aparat penegak hukum sampai pada proses persidangan yang mana jakwa menuntut Wisni dengan pidana penjara selama 4 (empat) bulan sesuai dengan ketentuan
Pasal 27 ayat (1) UU No. 11 Tahun 2008 Tentang ITE. Lebih jelasnya berikut isi ketentuan Pasal 27 ayat (1): "Mendistribusikan dan/atau mentransmisikan dan/atau membuat dapat diaksesnya informasi elektronik dan/atau dokumen elektronik yang memiliki muatan yang melanggar kesusilaan secara berlanjut."

Dalam proses pembuktian penuntut umum mengajukan alat bukti berupa print out 500an lembar percakapan antara Wisni dengan Nugraha. Bertolak dari alat bukti ini Pengadilan Negeri Bandung melalui Putusannya 1337/Pid.B/2014/PN.Bdg.

No. meyakini dan menjatuhkan pidana selama 5 (lima) Bulan Penjara yang justru lebih berat dari tuntutan jaksa. Dalam putusannya majelis hakim menyatakan terdakwa secara sah dan meyakinkan melakukan tindak pidana mentransmisikan informasi elektronik yang memiliki muatan melanggar kesusilaan. Atas putusan Pengadilan Negeri Bandung tersebut, terdakwa melakukan upaya hukum banding di Pengadilan Tinggi Bandung.

Majelis hakim yang terdiri dari hakim Karel Tuppu, Lexsi Mamonto, Edwarman menyatakan bahwa bukti yang diajukan penuntut umum berupa lembaran print out tidak bisa dijadikan alat bukti sebab tidak dilengkapi dengan uji laboratorium digital forensik. Dalam pertimbangannya, majelis hakim menilai chatting antara terdakwa dengan Nugraha Mursyid tidak dapat meyakinkan hakim karena print out asli tidak dapat diajukan dalam persidangan. Dengan demikian keotentikannya 
tidak

dapat

dipertanggungjawabkan. Dokumen elektronik yang keotentikannya tidak dapat dipertanggungjawabkan tidak dapat dipertimbangkan sebagai bukti yang sah dalam perkara Wisni Yetti. Sederhananya, setiap dokumen elektronik yang dijadikan alat bukti harus melalui proses pembuktian laboratorium terkait dengan keasliannya.

Putusan Pengadilan Negeri Pekan Baru No. 465/Pid.Sus/2017/PN. Pbr, Jumat tanggal 25 Agustus 2017 dan Putusan Pengadilan Negeri Muari No. 91/Pid.Sus/2018/PN. Mrj, Senin 13 Agustus 2018 juga menunjukkakn hal serupa. Hakim dengan mempertimbangkan pikiran ahli yang diajukan dalam persidangan memandang bahwa sahnya informasi atau dokumen elektronik sebagai alat bukti diukur dari dua aspek yaitu:

1. aspek formil, merujuk pada ketentuan Pasal 5 ayat (4) UU ITE, bahwa informasi atau dokumen elektronik terbut bukanlah:

a. surat yang menurut undangundang harus dibuat dalam bentuk tertulis; dan

b. surat beserta dokumennya yang menurut undang-undang harus dibuat dalam bentuk akta notariil atau akta yang dibuat oleh pejabat pembuat akta.

2. aspek materiil, merujuk pada ketentuan Pasal 6 UU ITE yaitu dapat diakses, ditampilkan, dijamin keutuhannya dan dapat dipertaggungjawabkan sehingga menerangkan suatu keadaan. Oleh karenanya dibutuhkan suatu uji digital forensik.
Pentingnya hasil uji digital forensik untuk menentukan dapat digunakannya dokumen elektronik sebagai alat bukti oleh hakim ditemukan pula pada Putusan Pengadilan Negeri Jakarta Timur No. 421/Pid.Sus/2018/ PN Jkt. Tim. Berdasarkan rangkaian jawabmenjawab antara penasihat hukum dan penuntut umum melalui pledoi, replik dan seterusnya dapat dipahami bahwa hakim memperhatikan betul hasil uji digital forensik sebagai bagian yang menyertai pengajuan alat bukti elektronik. Demikian misalnya pembelaan dari penasihat hukum terdakwa menitik beratkan pada alat bukti yang tidak sah. Sikap tersebut didasarkan pada keberadaan lima alat bukti yang tidak dapat diakses. Kelimanya yaitu: Surat keterangan kependudukan, Handphone, memory card, sim card dan satu bendel screenshot/print out postingan facebook. Penasihat hukum juga mempersoalnya mengenai uji laboratorium forensik terhadap alamat URL dimana akun twitter tersebut di upload. Dalam pandangannya, bukti yang diajukan dalam bentuk alamat URL tersebut tidak pernah dilakukan uji digital forensik. Oleh karenanya penuntut umum dianggap gagal dalam membuktikan dakwaannya. Atas pledoi dari penasihat hukum, penuntut umum memberikan tanggapan dalam repliknya bahwa mengenai alat bukti berupa informasi/dokumen yang diajukan elektronik telah memenuhi ketentuan Pasal 6 UU ITE, demikian diperkuat oleh keterangan ahli digital forensik yang diajukan oleh 
penuntut umum. Pada intinya bukti elektronik telah melalui proses uji digital forensik yang dilakukan oleh pakar di lingkungan Laboratorium Cyber Forensik Bareskrim Polri. Hasil uji digital forensik menyatakan bahwa bukti elektronik tersebut tidak teredit dan utuh serta tidak terpotong.

Menariknya dalam putusannya hakim dengan mempertimbangkan pledoi dari penasihat hukum yang pada intinya ketidakabsahan bukti elektronik yang diajukan penuntut umum karena bertentangan dengan Pasal 6 UU ITE, memberikan pertimbangan bahwa pada esensinya barang bukti merupakan elemen pelengkap dari alat bukti sebagaimana diatur dalam ketentuan Pasal 184 KUHAP yaitu melengkapi keterangan saksi, melengkapi keterangan terdakwa, melengkapi pendapat ahli maupun melengkapi petunjuk. Hakim memandang dengan adanya pembenaran dari terdakwa maka alat bukti yang diajukan dipandang cukup memadai dan barang bukti (bukti elektronik) merupakan pendukung dari alat bukti lainnya berupa keterangan saksi. Lebih lanjut majelis hakim memberikan pertimbangan bahwa bilamana prosedur penentuan alat bukti oleh penuntut umum belum atau tidak memenuhi aturan hukum yang berlaku, hal tersebut tidak mengurangi keyakinan hakim dalam mengadili.

Langkah terakhir yang dilakukan oleh hakim dalam rangka menentukan dokumen elektronik sebagai bukti dalam peradilan pidana yaitu dengan memeriksa adanya penyangkalan dari pihak lawan baik penuntut umum atau penasihat hukum mengenai keberadaan dokumen elektronik yang diajukan tersebut. Jika pihak terdakwa membenarkan bahwa bukti yang diajukan oleh penuntut umum memang sesuai dengan kenyataan yang dialaminya serta menerangkan suatu kebenaran maka hakim akan mempertimbangkan bahkan menjadi bagian yang menimbulkan keyakinan dalam putusannya. Putusan Pengadilan Negeri Jakarta Timur No. 421/Pid.Sus/2018/ PN Jkt. Tim menunjukkan hal demikian. Majelis hakim mempertimbangkan bahwa terdakwa telah membenarkan keterangan saksi-saksi mengenai informasi elektronik dalam dakwaan penuntut umum adalah benar dimuat dalam akun twitter terdakwa.

\section{Parameter Suatu Bukti Elektronik} Yang Dapat Digunakan Sebagai Alat Bukti Dalam Peradilan Pidana

Dalam rangka menentukan suatu bukti elektronik dapat digunakan sebagai alat bukti dalam peradilan pidana dibutuhkan suatu parameter yang fungsinya sebagai tolak ukur. Parameter ini kemudian dijadikan pedoman bagi hakim dalam memeriksa perkara khususnya dalam proses pembuktian yang selanjutnya dapat ditentukan apakah alat bukti elektronik yang diajukan dapat dijadikan dasar pertimbangan ataukah harus dikesampingkan. Untuk keperluan itu, peneliti mencoba menelusuri dari bahan hukum primer berupa ketentuan dalam peraturan perundang- 
undangan yang selanjutnya dikombinasikan dengan data primer yang diperoleh melalui hasil wawancara dengan narasumber di lapangan.

Secara implisit parameter yang dimaksud dapat ditemukan dalam ketentuan Pasal 6 UU ITE. Dengan tujuan memberikan gambaran yang utuh peneliti mengutip isi dari pasal tersebut secara lengkap sebagai berikut: "Dalam hal terdapat ketentuan lain selain yang diatur dalam Pasal 5 ayat (4) yang mensyaratkan bahwa suatu informasi harus berbentuk tertulis atau asli, Informasi Elektronik dan/atau Dokumen Elektronik dianggap sah sepenjang informasi yang tercantum di dalamnya dapat diakses, ditampilkan, dijamin keutuhannya, dan dapat dipertanggungjawabkan sehingga menerangkan suatu keadaan." Berdasarkan ketentuan tersebut peneliti merumuskan parameter suatu bukti elektronik antara lain:

informasi yang terkandung didalamnya dapat:

1. diakses;

2. ditampilkan;

3. dijamin keutuhannya;

4. dipertanggungjawabkan.

Mengenai maksud dari masingmasing istilah tersebut, UndangUndang terkait tidak memberikan penjelasannya. Oleh karenanya, dengan menggunakan interpretasi gramatikal peneliti mencoba mencari penjelasan tentang istilah tersebut melalui bahan hukum tersier.

Pertama, arti kata dapat diakses. "Akses" merupakan kata Bahasa Indonesia yang diserap dari Bahasa Inggri "access" yang berarti jalan masuk. Berdasarkan Kamus Besar Bahasa Indonesia (KBBI) daring kata "akses" diartikan pencapaian berkas di disket untuk penulisan atau pembacaan data. Rupanya arti ini tidak sepenuhnya dapat memberikan gambaran yang kontekstual sesuai kebutuhan praktis penelitian ini. Peletakan kata "disket" perdefinisi tersebut memberikan pembatasan ketat mengenai lingkup arti yang dituju. Padahal, kata tersebut telah mengalami kehilangan arti mengingat perkembangan teknologi yang sedemikian pesat (disket dewasa ini tidak lagi menjadi media penyimpanan data yang secara umum digunakan). Kendati demikian, dapat digali prinsip inti dari pembatasan tersebut yang utamanya dapat diakses berarti "dapat dicapai" (ketercapaiannya disesuaikan dengan kebutuhan misalnya menggunakan penangkapan panca indra seperti dibaca, ditonton, didengar, disentuh, dirasakan dan lain sebagainya). Diartikan dapat dicapai/jalan masuk dalam rangka penulisan dan pembacaan data.

Masih dalam substansi yang sama, dunia praktis yang terwujud dalam putusan hakim menerangkan arti frasa "dapat diskses" sebagai keadaan yang dapat dibuka, dibaca. Merujuk pada putusan pengadilan No. 471/Pid.Sus/2013/PN. Slmn yang memuat keterangan ahli di bidang Data Center Id-SIRTII (Indonesia Security Incident Response Team Of Internet Infrastructure) suatu lembaga partisipasi masyarakat yang dibentuk oleh Menteri Komunikasi dan Informatika berdasarkan 
Peraturan Menteri Kominfo No. 27 /2006 dan 26/2007 dapat ditemukan bahwa dapat diakses diartikan sebagai bisa dibaca dan dilihat orang lain. Dengan substansi yang sama kata arti akses dapat ditemukan dalam ketentuan Pasal 1 angka 15 UU ITE yang menyatakan akses sebagai kegiatan melakukan Interaksi dengan sistem elektronik yang berdiri sendiri atau dalam jaringan.

Kedua, arti kata dapat ditampilkan. "Menampilkan" dalam KBBI diartikan membawa ke muka, mengemukakan, mempertontonkan, memajukan. Adanya awalan 'di' merubah struktur kata menjadi pasif dengan arti dikemukakan, dipertontonkan dan dimajukan. Perdefinisi ini peneliti memahami bahwa yang dimaksud dengan dapat ditampilkan adalah dapat dipertontonkan atau dapat dikemukakan sehingga dilihat oleh pihak-pihak yang berkepentingan.

Ketiga, dapat diijamin keutuhannya. Kata dasar 'utuh' menurut KBBI diartikan sebagai keadaan sempurna sebagaimana adanya atau sebagaimana semula dalam arti tidak berubah, tidak rusak dan tidak berkurang. Dengan demikian peneliti memahami frasa dapat dijamin keutuhannya berarti dapat dijamin bahwa bukti elektronik tersebut sempurna keadaannya seperti sediakala, tidak berubah, tidak rusak dan tidak berkurang.

Keempat, dapat dipertanggungjawabkan.

Pemahaman dasar yang harus tuntas dalam menguraikan frasa "dapat dipertanggungjawabkan" ini adalah kata tanggungjawab. KBBI memberikan arti dari tanggungjawab sebagai "keadaan wajib menanggung segala sesuatunya". Bila terjadi sesuatu yang berpotensi menimbulkan akibat maka orang yang bertanggungjawab berarti dapat dituntut, dipersalahkan atau diperkarakan oleh karenanya. Sejalan dengan itu, frasa dapat dipertanggunjawabkan

dikonsepkan sebagai suatu keadaan (lahir dari perbuatan atau hal yang sifatnya kebendaan) yang dapat dibebani pertanggungan atas segala sesuatunya yaitu konsekuensi hukum kepada pihak yang menyebabkan keadaan itu lahir. Per konsep tersebut, jika dikontekskan dengan parameter keempat ini bahwa frasa "informasi yang terkandung di dalamnya dapat dipertanggungjawabkan" berarti konten dari Informasi Elektronik dan/atau Dokumen Elektronik tersebut dapat dibebani pertanggungan berupa konsekuensi hukum melalui proses penuntutan.

\section{Kesimpulan}

Berdasarkan uraian pada bagian hasil dan pembahasan tersebut dapat peneliti simpulkan sebagai jawaban atas permasalah yang telah dirumuskan sebelumnya sebagai berikut:

1. Hakim menentukan bukti elektonik yang dapat dijadikan alat bukti dalam peradilan pidana dengan cara: (1) memeriksa sumber dan cara perolehan dokumen elektronik yang diajukan oleh penuntut umum/penasihat hukum dengan tujuan menjaga legalitasnya; (2) memeriksa dan menganalisa kelengkapannya berupa hasil uji 
laboratorium digital forensik; (3) memeriksa adanya penyangkalan dari pihak lawan baik penuntut umum atau penasihat hukum mengenai keberadaan dokumen elektronik yang diajukan tersebut.

2. Parameter yang digunakan oleh hakim untuk menentukan bukti elektronik yang dapat dijadikan alat bukti dalam peradilan pidana yaitu informasi yang terkandung dalam bukti elektronik tersebut dapat: (1) diakses; (2) ditampilkan; (3) dijamin keutuhannya; dan dipertanggungjawabkan.

\section{Saran}

Berangkat dari uraian sebelumnya peneliti secara khusus merekomendasikan kepada aparat penegak hukum yang menggunakan bukti elektronik sebagai bukti dalam peradilan pidana agar mencermati, menganalisa dan melengkapinya dengan hasil uji laboratorium digital forensik dalam rangka menjamin orisinalitas dari bukti elektronik yang diajukan tersebut. Dengan demikian peluang untuk dapat dipertimbangkan oleh hakim menjadi menjadi alat bukti pada putusannya akan lebih besar.

\section{Daftar Pustaka}

Abi Ja'man Kurnia, "Keabsahan Faksimile Sebagai Alat Bukti", Hukum Online, https:/ / www.hukumonline.co $\mathrm{m} / \mathrm{klinik} /$ detail/ulasan/lt4d41 34d98d224/keabsahanfaksimile-sebagai-alat-bukti, Diakses pada 14 September 2019.
Andi Saputra, "Belajar Dari Kasus Chatting Istri Di FB Yang Dipidanakan Suaminya", Detik News.com, 31 Agustus 2015, https://news.detik.com/berita/ d-3005343/belajar-dari-kasuschatting-istri-di-fb-yangdipidanakan-suaminya, Diakses pada 10 Januari 2019.

Apeldoorn, L.J. van. 1978, Pengantar Ilmu Hukum. Jakarta: Pradnya Paramita.

Badan Pengembangan Bahasa dan Perbukuan, 2016, Kamus Besar Bahasa Indonesia: Online, Kementerian Pendidikan dan Kebudayaan Republik Indonesia, https://kbbi.kemdikbud.go.id/. Bahri, Zainul. 1996, Kamus Umum Khususnya Bidang Hukum dan Politik. Bandung: Angkasa.

Dahlan, "Distorsi Beban Pembuktian Dalam Tindak Pidana Korupsi Menurut Sistem Pembuktian", Samudra Keadilan, Vol. 10., No. 1, Januari-Juni 2015.

Dedy Muchti, Nugroho, “Eksistensi Alat Bukti Elektronik Dalam Sistem Hukum Pembuktian Di Indonesia Dari Perspektif Hakim", QISTIE, Vol. 8, No. 1, Mei 2015.

Dimas Hutomo, "Keabsahan Alat Bukti Elektronik Dalam Hukum Acara Pidana", Hukum Online, https:/ / www.hukumonline.co $\mathrm{m} / \mathrm{klinik} /$ detail/ulasan/lt5c4ac 8398c012/keabsahan-alat-buktielektronik-dalam-hukum-acarapidana, Diakses pada 14 September 2019.

Hariati Kalia, "Pembuktian Tindak Pidana Dengan TerangTerangan Dan Tenaga Bersama 
Menggunakan Kekerasan

Terhadap Orang Yang

Mengakibatkan Luka-Luka

(Studi Putusan Nomor: 256/PID.B/2010/PN.DGL),

Jurnal Ilmu Hukum Legal Opinion, Volume 1, Nomor 4, 2013.

Hiariej, Eddy O.S. 2012, Teori Dan Hukum Pembuktian. Jakarta: Erlangga.

Marzuki, Peter Mahmud. 2013, Penelitian Hukum Edisi Revisi.Jakarta: Kencana.

Mertokusumo, Sudikno. 1996, Penemuan Hukum Sebuah Pengantar. Yogyakarta: Liberty.

Mutiara, Achmad Benny. 2007, Panduan Komputer Forensik Dalam Penangnan Bukti Digital Pada Personal Digital Assistants (PDA). Depok: Universitas Gunadarma.

Nur Laili Isma dan Arima Koyimatun, "Kekuatan Pembuktian Alat Bukti Informasi Elektronik Pada Dokumen Elektronik Serta Hasil Cetaknya Dalam Pembuktian Tindak Pidana", Jurnal Penelitian Hukum, Vol 1, No. 2, Juli 2014.

Putusan Mahkamah Konstitusi Republik Indonesia Nomor 20/PUU-XIV/ 2016.

Putusan Pengadilan Negeri Bandung Nomor 1337/Pid.B/2014/PN.Bdg.

Putusan Pengadilan Negeri Jakarta Timur No. 421/Pid.Sus/2018/ PN Jkt. Tim.

Putusan Pengadilan Negeri Muari Nomor 91/Pid.Sus/2018/PN. Mrj, Senin 13 Agustus 2018.

Putusan Pengadilan Negeri Pekan Baru No.
465/Pid.Sus/2017/PN. Pbr, Jumat tanggal 25 Agustus 2017. Putusan Pengadilan Tinggi Bandung Nomor 178/Pid.SusITE/2015/PT.BDG.

Riki Perdana Raya Waruwu, "Eksistensi Dokumen Elektronik Di Persidangan Perdata", Mahkamah Agung Republik Indonesia, https://www.mahkamahagung .go.id/id/artikel/3048/eksisten si-dokumen-elektronik-dipersidangan-perdata, Diakses pada 12 September 2019.

Ronaldo Ipakit, “Urgensi Pembuktian Alat bukti Dalam Praktik Peradilan Pidana", Jurnal Lex Crimen, Volume IV, Nomor 2, April 2015.

Siswanto, Heni. 2007, Rekonstruksi Sistem Penegakan Hukum Pidana Menghadapi Kejahatan Perdagangan Orang. Jakarta: Pustaka Magister.

Undang-Undang Nomor 11 Tahun 2008 Tentang Informasi Dan Transaksi Elektronik (Lembaran Negara Republik Indonesia Tahun 2008 Nomor 58, Tambahan Lembaran Negara Republik Indonesia Nomor 4843) jo Undang-Undang Nomor 19 Tahun 2016 Tentang Perubahan Atas UndangUndang Nomor 11 Tahun 2008 Tentang Informasi Dan Transaksi Elektronik (Lembaran Negara Republik Indonesia Tahun 2016 Nomor 251, Tambahan Lembaran Negara Republik Indonesia Nomor 5952).

Undang-Undang Nomor 8 Tahun 1981 Tentang Hukum Acara Pidana (Lembaran Negara 
Republik Indonesia Nomor 76, Tambahan Lembaran Negara Republik Indonesia Tahun 1981 Nomor 3209).

Vento Saudale, "18 Kasus Polda Jabar Terpecahkan Berkat CCTV", Berita satu.com, 27 Oktober 2017, https://www.beritasatu.com/n asional/460412-18-kasus-poldajabar-terpecahkan-berkatcctv.html, Diakses pada 10 Januari 2019.

Yohanes Suhardin, "Fenomena Mengabaikan Keadilan Dalam Penegakan Hukum", Jurnal Mimbar Hukum, Volume 21, Nomor 2, Juni 2009.

Yurina Ningsi Eato, "Keabsahan Alat Bukti Dan Barang Bukti Pada Perkara Pidana", Lex Crimen, Vol. VI, No. 2, MaretApril 2017.

Yusuf, "Penerapan Sistem Pembuktian Terbalik Untuk Kasus Korupsi Kajian Antara Hukum Positif Dan Hukum Islam", Jurnal Episteme, Volume 8, Nomor 1, Juni 2013. 